\title{
ON THE CONCENTRATIONS OF SOME INORGANIC IONS AND PROTEIN NITROGEN IN RABBIT SEMINAL FLUID
}

\author{
D. FJELLSTRÖM AND J. E. KIHLSTRÖM \\ Institute of Zoophysiology, \\ Box 560, S-751 22 Uppsala, Sweden
}

(Received 15th January 1975)

In spite of the widespread laboratory use of the rabbit, no information about the concentrations of chloride ions and proteins in rabbit seminal fluid seems to be available in the literature (see White, 1958; Mann, 1964; Quinn et al., 1965). The aim of this paper is to present such data and some information concerning the concentrations of some cations obtained as by-products during work with another project.

Semen was collected by means of an artificial vagina (one ejaculate/day) from twelve rabbits of different breeds. After centrifuging at $975 \mathrm{~g}$ for $10 \mathrm{~min}$ spermatozoa were very seldom found in the supernatant. The concentrations of protein nitrogen and chloride ions in the seminal fluid were determined by the methods described by Lowry et al. (1951) and Kulhánek \& Fišer (1966), respectively. The standard deviations of the differences between duplicate determinations using known concentrations were 0.019 for protein nitrogen and 0.074 for chloride. The concentrations of sodium and potassium ions were determined by the methods of Smit et al. (1951) using a Beckman flame spectrophotometer (Gilbert et al., 1950).

Table 1. Concentrations of some constituents of rabbit seminal fluid

\begin{tabular}{lcc}
\hline & $\begin{array}{c}\text { Concentrations } \\
\text { (Mean } \pm \text { S.D.) }\end{array}$ & $\begin{array}{c}\text { No. of } \\
\text { determinations }\end{array}$ \\
\hline $\mathrm{Cl}^{-}$(mequiv./litre) & $99 \pm 7$ & 625 \\
Protein nitrogen (mg/100 ml) & $299 \pm 94$ & 818 \\
$\mathrm{Na}^{+}$(mequiv./litre) & $82 \pm 22$ & 777 \\
$\mathrm{~K}^{+}$(mequiv./litre) & $29 \pm 7$ & 777 \\
\hline
\end{tabular}

The mean values found are given in Table 1 . The concentration of chloride ions was close to those found in seminal fluid of bull (Cragle et al., 1958a, b), boar (Mann, 1964), and stallion (Yamane, 1920). The concentration of protein nitrogen was similar to that found in dog seminal fluid (Bartlett, 1962), and lower than that of many other species (Mann, 1964). The inorganic cation concentrations were similar to those previously reported for rabbit seminal fluid (Quinn et al., 1966), but these authors found a strong negative correlation 
$(r=-0.844)$ between $\mathrm{Na}^{+}$and $\mathrm{K}^{+}$in seminal plasma. In spite of the large number of values available, we were unable to confirm their observation $(r=$ $0 \cdot 0427, \mathrm{n}=777$ ). As previously reported in bull seminal fluid (Cragle et al., 1958a, b), a good correlation between the concentrations of sodium ions and chloride ions $(r=0.6263)$ was observed. No other correlations could be revealed.

This work was supported by a grant from the Swedish Natural Science Research Council.

\section{REFERENCES}

Bartlett, D.J. (1962) Studies on dog semen. II. Biochemical characteristics. F. Reprod. Fert. 3, 190205.

Cragle, R.G., Salisbury, G.W. \& VanDemark, N.L. (1958a) Sodium, potassium, calcium, and chloride distribution in bovine semen. F. Dairy Sci. 41, 1267-1272.

Cragle, R.G., Salisbury, G.W. \& Muntz, J.H. (1958b). Distribution of bulk and trace minerals in bull reproductive tract fluids and semen. F. Dairy Sci. 41, 1273-1277.

Gilbert, P.T., Hawes, R.C. \& Beckman, A.O. (1950) Beckman flame spectrophotometer. Analyt. Chem. 22, 772-780.

KulháNEK, V. \& FIšER, C. (1966) Einfache kolorimetrische Methode zur Chloridbestimmung in biologischen Material. Colln Czech. chem. Commun. 31, 1890-1893.

Lowry, O.H., Rosebrough, N.J., FARR, A.L. \& Randall, R.J. (1951) Protein measurement with the Folin phenol reagent. F. biol. Chem. 193, 265-275.

ManN, T. (1964) The Biochemistry of Semen and of the Male Reproductive Tract. Methuen \& Co., London.

QuinN, P.J., WhITE, I.G. \& WIRRIGK, B.R. (1965) Studies of the distribution of the major cations in semen and male accessory secretions. F. Reprod. Fert. 10, 379-388.

Smit, J., Alkemade, C.T.J. \& Verschure, J.G.M. (1951) A contribution to the development of the flame-photometric determination of sodium and potassium in blood serum. Biochim. biophys. Acta 6, 508-523.

White, I.G. (1958) Biochemical aspects of mammalian semen. Anim. Breed. Abstr. 26, 109-123.

Yamane, J. (1920) Studien über die physikalische und chemische Beschaffenkeit des Pferdespermas mit besonderer Berücksichtigung der Physiologie der Spermatozoen. 7. Coll. Agric., Sapporo 9, 161-236. 